

REALA, n 1, enero-junio 2014, ISSN: 1989-8975

DOI: http://dx.doi.org/10.24965/reala.voi1.10139

\title{
La búsqueda de los orígenes de la administración municipal: de la Edad Media al Liberalismo
}

\author{
Ana Cristina Pérez Rodríguez \\ Universidad de La Coruña \\ anacristinpr@yahoo.es
}

Recibido: 26 de noviembre de 2013

Aceptado: 27 de noviembre de 2013

Resumen

El presente artículo trata de buscar las raíces históricas del municipio y su órgano de gobierno, el ayuntamiento. Desde una perspectiva revisionista de la abundante bibliografía producida durante los siglos XIX y XX se ha tratado de incidir en la desmitificación de ciertos presupuestos que abundaban en la autonomía y el autogobierno de las entidades municipales en la Edad Media, la creación de un modelo político administrativo totalmente nuevo por parte del Liberalismo o bien el éxito de las políticas centralizadoras llevadas a cabo por la Monarquía en su proceso de fortalecimiento del Estado a costa de los entes locales.

Palabras clave

Revisión bibliográfica; centralización, gobierno municipal.

\section{The Search of the Origins of the Municipal Administration: from the Middle Ages to the Liberalism}

\section{Abstract}

This paper tries to find out the historical roots of the municipality and their executive branch, the city council. From a revisionist perspective of the bibliography produced during the nineteenth and twentieth centuries, we have tried to demystify some assumptions about the municipal autonomy and self-government in the Middle Age, the debate about the setting up of an entirely new political administrative model by the Liberalism and the success of the centralizing policies executed by the Monarchy during the process of state strengthening at expense of local entities.

Keywords

Bibliographic review, Centralism, Municipal government. 


\section{MUNICIPIOS Y AYUNTAMIENTOS: LOS ORÍGENES}

El presente artículo tratará de desentrañar el asentamiento, desarrollo y evolución de la dimensión política del Ayuntamiento y del gobierno local, desde su nacimiento hasta el asentamiento del liberalismo. Así, desde una perspectiva de revisión historiográfica describiremos como la conversión del concejo abierto en cerrado y el centralismo, traducidos ambos como menor grado de representación ciudadana en los actos y decisiones públicas, figuraron como elementos esenciales en la creación de municipios y ayuntamientos pero con grandes desigualdades en el tiempo y en el espacio.

Los ayuntamientos, tal y como los conocemos hoy en día, se fueron configurando a lo largo del tiempo mediante la combinación de elementos recuperados de etapas anteriores y dotados de una nueva dimensión político administrativa y otros principios nuevos procedentes en su mayoría de la administración y la política francesas. A esta combinación se fueron añadiendo componentes que fueron surgiendo a tenor de las necesidades reales del país y sobre todo de los gobiernos liberales. De este modo se fueron configurando los municipios y sus órganos de gobierno, los ayuntamientos, perdurando hasta casi nuestros días con modificaciones y nuevos contenidos dictados por la división de poderes y la democracia'.

La búsqueda del nacimiento del "municipio" y de sus antecedentes históricos, ha producido a una rica historiografía en la que destacan autores como García Valdeavellano que defiende la existencia de municipios en el proceso de romanización de la península donde los ciudadanos o cives de la Bética y la Tarraconense, y posteriormente todas las provincias elegían a las magistraturas que le representarían y se reunían en "asamblea" para dirimir asuntos funcionales de gobierno ${ }^{2}$

Para otros investigadores los primeros pasos del municipalismo se remontarín a la Edad Media y a la aparición de figuras jurídico administrativas, como el "ludex" y el "Comes", y territoriales como los "distritos"’.

Además del origen confuso del nacimiento del municipio, los especialistas tampoco logran un acuerdo amplio sobre el momento preciso en el que las decisiones dejaron de tomarse en asamblea para ser tomadas por representantes, o lo que es lo mismo, el paso de los concejos abiertos a cerrados La mayor parte de los estudiosos atribuyen el nacimiento del concejo cerrado a la extensión de la Reconquista y a las nuevas necesidades que provocó para obtener recursos y gestionar el crecimiento poblacional ${ }^{4}$. En general, existe un acuerdo en que desde el siglo XI la mayor parte de las ciudades tenían que estar gobernadas por concejos cerrados y que las decisiones eran tomadas por unos pocos denominados "boni homines"s.

El proceso de la Reconquista y en particular la concesión de un conjunto de privilegios y exenciones denominadas "fueros" parecen haber sido el origen directo del concejo cerrado ya que los vecinos podían decidir si querían reunirse en asamblea o bien en concejo cerrado o ayuntamiento ${ }^{6}$. Sin embargo, la ingobernabilidad de

1 El Artículo 140 de la Constitución de 1978 afirma que el gobierno y la administración de los municipios corresponden a los ayuntamientos de cada uno de ellos y que estos ayuntamientos están integrados por los alcaldes y concejales. En la actualidad, el Diccionario Espasa Jurídico, basándose en conceptos previos e inherentes a ambas realidades, como son el territorio y la población, define el “municipio” como la institución y el "Ayuntamiento" como el órgano que la gobierna y administra.

2 GARcía de VALdeAVElLANo (1973); PÉREZ PuYOL, E. (1986). El nombre que recibía la asamblea era “Curia” o "Senado” y en ella participaban todos los “cives" hasta que en el siglo II se fue constituyendo en poder oligárquico.

3 La instalación de los visigodos supuso la afirmación de una administración centralizada al estilo del Bajo Imperio Romano, organizada en distritos dotados de competencias administrativas y judiciales. Al frente de estas unidades administrativas se pusieron dos autoridades, el ludex y el Comes, dependiendo del tipo e importancia de las mismas. El "ludex" era un nuevo funcionario procedente de la Corte visigótica que ejercía sus poderes administrativos y judiciales junto a la Curia, a la que tutelaba y vigilaba. El "Comes" estaba dotado de atribuciones judiciales, policiales, administrativas e incluso militares. Ver: SÁNCHEZ ALBORNOZ, C. (1943) y (1976). Autores como Orduña Rebollo son partidarios de que el Comes era una autoridad enviada teniendo en cuenta factores políticos de proximidad al Rey o la importancia de una ciudad en particular para este. ORDUÑA REBOLLO, E. (2003), pp. 20-21.

4 La Reconquista fue un proceso de colonización de tierras donde el Rey otorgaba a los pobladores una extensión de terreno en régimen de propiedad y con la obligación de compartir recursos comunes como prados, molinos, agua, montes, entre otros. Estas primeras colonias adoptaron, como forma de organización para dirimir sus asuntos y defender sus privilegios, la asamblea municipal llamada "concejo abierto". ORDUÑA REBOLLO, E. (2003).

5 Los "boni homines" no constituían una clase social sino un cargo referido a varias instituciones jurídicas y en particular designaba un conjunto de personas de cualquier clase social que desempeñaban por un tiempo limitado funciones de jurisdicción voluntaria y contenciosa. Desde el siglo XII fue también el nombre de algunos oficios administrativos y políticos. MERCHÁN FERNÁNDEZ, C. (1983); FONT RIUS. J. M. (1949), p. 389 y ss.

6 Valdeón Baruque define al Concejo Abierto como "reunión de comunidades" bien sea de feligreses, vecinos, etc., pero sobre todo "de la propia comunidad convocada en asamblea para autogobernarse". Según este autor en esas asambleas participaban todos los vecinos sin exclusión por sexo, edad, orden social, y tendrían carácter rural. Estas asambleas son algo nuevo y darán lugar al municipio cuando tengan un grado más alto de organización y vayan consiguiendo cierta autonomía. De todos modos no todos los autores están de acuerdo en esto sino que existen otras teorías como la de Estepa. según el cual en una misma ciudad existían varios concejos abiertos porque era un recinto amurallado y rodeado por un extenso territorio (alfoz o término municipal) que se dividía en aldeas cada una con su propio concejo como la propia ciudad. Ver VALDEÓn BARUQUE, J. (1985). 
las ciudades grandes así como la mayor injerencia del poder señorial en los asuntos de villas y ciudades conllevaron la paulatina desaparición de las asambleas como marco de gobierno.

La historiografía del siglo XIX fue especialmente prolífica en estudios sobre la administración local. Sin embargo, los trabajos publicados carecen de una metodología crítica y responden básicamente a la necesidad de buscar elementos históricos que sustentasen los distintos proyectos de Estado liberal que se estaban fraguando.

La línea historiográfica más progresista en la que se insertaba Martínez Marina interpretó el reinado de Alfonso $\mathrm{XI}$ y su ordenamiento de Alcalá como el golpe maestro en contra de las libertades concejiles y la capacidad de los municipios de legislar sobre sus asuntos. Dentro de esta línea, profesionales como, Hinojosa, Gumersindo de Azcárate o Elías, atribuían a la política y administración absolutistas la desaparición de las libertades municipales, a la vez que idealizaban esas libertades ${ }^{8}$. En la línea más liberal está también Eduardo de Hinojosa y Naveros, quien ofreció una cronología sobre la evolución de los municipios, iniciando el régimen municipal en la Edad Media (s. X-XIII) donde las decisiones se tomaban entre los vecinos por votación y una segunda etapa (s.XIV y XV), donde la representación se reservaba a unos pocos y se patrimonializaban los cargos públicos.

La línea más conservadora representada por Juan Sempere y Colmeiro defendía las reformas llevadas a cabo por Austrias y Borbones y en particular el centralismo como instrumento de control eficaz. Juan Sempere ${ }^{9}$ abogaba por una monarquía centralista, resaltando la eficacia de las reformas administrativas borbónicas. En su "Historia del Derecho español", se refería al Estado como tutor de los municipios tratando de evitar los abusos de los señores en su mala praxis de la autonomía municipal. Por su parte, Manuel Colmeiro ${ }^{10}$ en su "De la Constitución y del gobierno de los reinos de León y Castilla" dibujaba una situación caótica en los municipios leoneses y castellanos que provocó la intervención de la monarquía tratando de evitar la desorganización legislativa y los enfrentamientos por los cargos públicos. Mucho más radical y próximo al absolutismo estaba Fernando Cos-Cayón, partidario de la intervención monárquica como garantía de la unidad del Estado.

La historiografía sobre la administración local y más concretamente sobre el municipio fue extensa y fue constituyendo un sustrato histórico e intelectual sobre el que se plantearían distintos modelos de gobierno municipal. Esas ideas fueron recogidas a lo largo del siglo XIX por los diferentes gobiernos en función de la mayor o menor afinidad ideológica y fueron ensayadas en las distintas leyes de ayuntamientos que se promulgaron ${ }^{11}$.

Sin embargo estudios más recientes han puesto de relieve que no se puede generalizar y que mientras unos concejos se convirtieron en cerrados inmediatamente, otros como Palencia, Vizcaya, Salamanca o Madrid ${ }^{12}$, permanecieron como concejos abiertos hasta varios siglos más tarde, subsistiendo a veces como únicos y otras veces al lado de regimientos. A su vez, los cargos de los regimientos ${ }^{13}$ fueron enajenados por la Corona numerosas veces, pero también en muchos pueblos continuaron siendo electos hasta bien adentrada la época moderna, e incluso el siglo $\mathrm{XIX}^{14}$.

Por otro lado, tampoco fue el proceso de fortalecimiento del poder real el que eliminó en las grandes ciudades y villas de Castilla los concejos abiertos, instaló los regimientos y procedió a vender sus cargos de gobierno municipal; sino que desde el siglo XII, los caballeros y "boni homines" se fueron haciendo con el poder municipal de muchos pueblos acaparando sus oficios y cargos y desvirtuando cualquier autonomía municipal concedida”.

Como vemos, es imposible generalizar y mucho menos atribuir a unas mismas causas y una cronología los cambios sufridos por los municipios en la Edad Media, pero desde el reinado de Alfonso $\mathrm{XI}^{16}$, los monarcas

7 Martínez Marina, con su “Teoría de las Cortes”, planteaba la defensa de la Constitución de Cádiz, las Cortes y la Soberanía Nacional como elementos existentes ya en los reinos y cortes medievales. Para él, los fueros medievales habían constituido el germen de las libertades democráticas y de la representación ciudadana.

8 En el caso de Gumersindo de Azcárate y desde un punto de vista más profesional llegó a reconocer que el proceso de extensión de los concejos cerrados había sido discontinuo y centrado en el control político, dejando en manos de los municipios materias como: abastecimientos, hacienda o la higiene.

9 SeMPERE, J. (1815). Sempere pretendía contestar a Martínez Marina desde el campo jurídico.

10 La figura de Colmeiro ha sido muy estudiada, dedicándosele un congreso especial por parte de la Escola Galega de Administración Pública. Ver Gallego AnAbitARTe, A.; BARReiro FernándeZ, X.R.; GonZÁlez MARIÑAs, P. (1994).

11 Sobre la historiografía del municipio en la etapa moderna es imprescindible la obra PASOLA TEJEDOR, A. (1997).

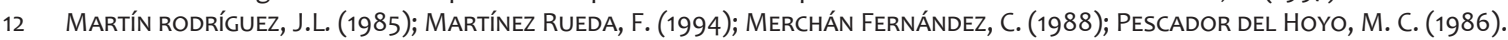

13 Los regimientos eran los sustitutos de los concejos abiertos o asambleas vecinales.

14 Palencia tuvo regimientos elegidos por sus ciudadanos hasta bien entrado el siglo XVI y en el caso de los pueblos de Guipúzcoa no se registra la venta y patrimonialización de cargos, sino que continuaron siendo elegidos hasta prácticamente el siglo XIX.

15 El "bonus homo" era un concepto más amplio que el de "caballero", a pesar de que muchas veces coincidiesen ambos conceptos en una misma persona. El momento de acceso de los caballeros a los cargos municipales fue durante el siglo XII y XIII fundamentalmente y se produjo en muchas poblaciones, sobre todo las más grandes.

16 Las particularidades de cada provincia, y sobre todo las irregularidades del proceso, han servido a muchos autores para concluir que Alfonso XI al dictar las Ordenanzas de Alcalá estaría institucionalizando una situación muy habitual en las ciudades y pueblos, es decir regulari- 
profundizaron en el proceso irreversible de centralización del poder, la venta de oficios municipales y el envío de funcionarios reales a los pueblos para representar a la Corona y vigilar su comportamiento ${ }^{17}$. El envío de corregidores ${ }^{18}$ constituyó un hecho fundamental dentro del proceso de centralización, así como también lo fue la manera paulatina en la que fueron enviados debido a carencia de recursos económicos y a que era necesario evitar la confrontación directa con los municipios. Con el tiempo se les aumentó en número y funciones, lo que añadido al esfuerzo que suponía su sueldo a los pueblos, les convirtió en el cargo público más odiado.

Los primeros estudios realizados sobre esta figura apuntan a que el corregidor era un término común para designar a los jueces que la Corona enviaba a las poblaciones con carácter de "Jueces de salario" y "alcaldes veedores"19. Esta es la hipótesis de Castillo de Bovadilla ${ }^{20}$, Villadiego ${ }^{21}$, Martínez Marina ${ }^{22}$, Colmeiro ${ }^{23}$ y Ortiz de Zúñiga ${ }^{24}$. Ya en el siglo XX, los trabajos de García Gallo demuestran que aunque los cargos estaban relacionados, no contaban con las mismas funciones, y que por lo tanto podían coexistir en los pueblos siendo el corregidor el superior jerárquico de los alcaldes ${ }^{25}$. Para otros autores como Albi y González Alonso ${ }^{26}$, los corregidores eran funcionarios reales, con atribuciones genéricas y un objetivo de administración de justicia durante un tiempo determinado, con un protocolo de actuación definido y a un lugar muy concreto. Cuando alcanzaban su misión podían ser reemplazados o no, y eran sometidos a un juicio de residencia donde un funcionario real se encargaba de evaluar su gestión.

Estos funcionarios podían ejercer solos su cometido, pero si carecían de formación jurídica (corregidores de capa y espada), eran asistidos por un ayudante. El corregidor representaba la autoridad real en el pueblo, y aunque en un principio no podían ser vendidos ni patrimonializados, pronto fueron también enajenados, aunque en menor medida que otros oficios.

La actividad del corregidor estaba limitada al pueblo donde desempeñaba su puesto de trabajo y sus competencias eran fundamentalmente jurisdiccionales, tanto en materia civil como penal. Sus funciones abarcaban desde la instrucción del proceso hasta la decisión sobre el caso en concreto, anulando las funciones del alcalde forero. Con el paso del tiempo el corregidor consiguió aumentar sus atribuciones abarcando competencias policiales, administrativas y político-gubernativas, entre las que se incluía la presidencia del ayuntamiento donde residía ${ }^{27}$.

\section{LA ETAPA MODERNA: EL DESARROLLO DE LAS ESTRUCTURAS ADMINISTRATIVAS MUNICIPALES}

El paso de la Edad Media a la etapa Moderna ${ }^{28}$ no supuso una ruptura definitiva con el sistema administrativo local existente, sino más bien una consolidación de las entidades territoriales que se habían ido formando. Así, las reformas administrativas de los Austrias sólo profundizaron en la gran diversidad estructural de municipios que dio origen a distintas tipologías municipales, tales como el municipio castellano, el valenciano, el catalán, el aragonés, etc., cada uno de ellos con particularidades locales relacionadas con las costumbres o el territorio. En

zando desde la monarquía el funcionamiento de los regimientos creados ya desde hacía mucho tiempo. GUBERT; SÁNCHEZ DE LA VEGA, R. (1949). 17 Corral García, E. (1988).

18 La figura del corregidor aparece por primera vez en el Cuaderno de Peticiones a las Cortes de Alcalá de 1348, con carácter de oficial real especializado en justicia o en armas. Sobre el nacimiento de este cargo hay varias hipótesis, pero lo fundamental es conocer como se convirtió en instrumento del poder real para llegar a los lugares más recónditos del territorio. MERCHÁN FERNÁNDEZ, C. (1988), p.38-39.

19 Se trataba de un "alcalde veedor" o un "alcalde mayor". Ambas figuras fueran introducidas por Alfonso X con el nombre de "Jueces”. Más tarde Sancho IV les dio el nombre de "Juyces de Salario" y “Juyces de Fuera Parte”, con funciones de justicia y de mantenimiento del orden. La diferencia entre ambos consistía en que los de "Fuera Parte”, eran foráneos a la población en la que ejercían funciones, hecho que fue utilizado para pedir que fuesen eliminados por no conocer las leyes locales. GoNZÁLEZ ALONSO, B. El corregidor castellano (1348-1808), 1970, pp. 30-35.

20 CASTILLO DE BOVADILLA (1750), p. 15

21 VILLADIEGo, I. (1776), p.147 y ss.

22 MARTÍNEZ MARINA, (1813).

23 COLMEIRO, M. (1855), p. 213. Colmeiro afirmaba que la tarea principal de Alfonso XI respecto al corregidor había sido agrupar las variantes terminológicas que servían para designar al enviado del Rey en las poblaciones en un solo término, que era el de corregidor.

24 ORTIZ DE ZúÑIGA, M. y HERRERA, C. Deberes y atribuciones de los corregidores, justicias y ayuntamientos de España. I, Madrid, 1832 , p. 8.

25 GARCía GALlo. Curso de historia del Derecho español, $5^{\text {a }}$ edición, 1950.

26 ALBI, F. El corregidor en el municipio español bajo la monarquía absoluta, Madrid.1943.; GonZÁLEZ ALONSO, B. El corregidor Castellano (1348-1808), Madrid, 1970.

27 Colmeiro. Cortes de los Antiguos Reinos de León y Castilla, Madrid, 1883.

28 El proceso centralizador estaba en marcha desde la Edad Media pero fueron los Reyes Católicos los que inauguraron una nueva forma de Estado y una nueva organización de la Administración y de esa manera constituyeron lo que se conocería como Estado Moderno. El objetivo era conformar un poder monárquico fuerte que diese cohesión interna a los reinos y para ello desarrollaron enormemente el ejército y la burocracia administrativa. Los Reyes Católicos eligieron como instrumento burocrático principal al corregidor medieval y no solo lo generalizaron a todo el territorio, sino que lo dotan de mayores competencias. El año 1480 fue el año clave en la generalización de los corregidores pues según las crónicas los reyes enviaron a estos delegados a todas las poblaciones importantes para que realizasen la labor de jueces en nombre de los reyes. 
esta etapa, los reyes trataron de encontrar el equilibrio entre la necesidad de intervenir en la configuración de las entidades territoriales y su forma de gobierno, y la venta de los oficios municipales al mejor postor para obtener recursos con los que financiar su maltrecha Hacienda y sus campañas militares.

En general, la historiografía considera que éste fue el momento en el que más se profundizó en la descomposición del poder municipal a través de la figura del corregidor y sus asistentes ${ }^{29}$. El corregidor fue fortalecido con competencias en materia de recaudación de impuestos, infraestructuras, obras públicas o sanidad $^{30}$, lo que supuso su consolidación como administrador principal al frente de los pueblos y por encima de los ayuntamientos y de sus miembros ${ }^{31}$. El incremento de competencias y el desarrollo urbano de los pueblos favorecieron que se les reforzase con nuevos funcionarios en calidad de ayudantes, denominados "logar tenientes". Esos asistentes fueron instituidos con carácter temporal y para tareas determinadas, pero pronto no sólo se generalizaron sino que fueron objeto de compraventa por parte de las elites locales². Los "lugartenientes" tenían la misma autoridad jurídica de su superior, cumplían los mismos requisitos para el cargo y su sueldo salía también de las arcas municipales, aunque no podían incorporar los oficios de alcalde y alguacilazgos.

En el funcionamiento diario de los municipios, intervenían también otras figuras como los regidores y una serie de cargos menores relacionados con los servicios. En un principio, el regidor tenía un carácter electivo y era desempeñado por los vecinos de mayor status social y económico, pero se convirtió en un oficio patrimonializado ${ }^{33}$, que fue vendiéndose a las élites locales a cambio de dinero líquido para la Corona ${ }^{34}$.

Las elites económicas invertían su dinero en la compra de oficios municipales esperando obtener prestigio social y decisiones políticas afines a sus intereses. Así, se repartían las regidurías, los jurados, las escribanías, las contadurías, las mayordomías, las veedurías, los puestos de medicina e higiene, las porterías, las alguacilerías, etc. ${ }^{35}$. La compra de uno u otro oficio, venía determinado por el estatus económico y social del demandante, de modo que si no se podía acceder al cargo de regidor, se podía comprar el de jurado o de escribano ${ }^{36}$. Esta diversidad de cargos públicos tenía su origen en la incapacidad del Estado para hacerse cargo de las necesidades de los pueblos, lo que los obligaba a asumir por si mismos la gestión de sus servicios más básicos. Los municipios con sus regimientos al frente y sus oficios públicos asumían los abastecimientos, la higiene y salubridad, el urbanismo e infraestructuras o los abastos. Por su parte el corregidor y sus ayudantes se encargaban del orden público y la policía urbana, la presidencia del Ayuntamiento y su control, la representación del poder de la Corona, etc.

\section{LAS REFORMAS DEL SIGLO XVIII}

La muerte de Carlos II supone el inicio de la Guerra de Sucesión (1701-1713) en la que Habsburgos y Borbones se disputan la Corona Española. El vencedor de la contienda fue Felipe de Anjou, que reinaría como Felipe V y que, nada más instalarse en el poder, inauguró un período extremadamente centralista en el que eliminó los fueros de que disfrutaban los territorios de la zona oriental de la península y los sustituyó por las leyes e instituciones que ya venían operando en la zona de Castilla.

Felipe $\mathrm{V}$ pretendía crear una administración centralizada y especializada que llegase a todo el territorio español y fuese un espejo del esquema administrativo francés. Para ello organizó la administración en torno a dos figuras principales: por un lado las capitanías generales ${ }^{37}$, dirigidas por un capitán general dotado de competencias militares y administrativas; y por otro lado las intendencias de hacienda, dirigidas por un intendente con competencias tributarias.

29 VIÑES MiLLET, C. (1994), p. 107.

30 La Pragmática del 12 de marzo de 1498, incorporó entre sus funciones las alcaldías, alguacilazgos y merindades existentes en los pueblos donde ejercía, de forma que al nombrar un corregidor para un pueblo cesaban inmediatamente estos oficios concejiles.

31 Existían dos tipos de corregidores: el "corregidor de Capa y Espada”, procedente de la baja nobleza y llamado así porque carecía de preparación jurídica y su función principal era pacificar zonas conflictivas o con problemas de orden público; y el “corregidor de Letras”, de extracción social media, pero con licenciatura en jurisprudencia, con presencia en cualquier municipio para ejercer todo tipo de funciones en nombre del Rey. GonzÁlez Alonso, B. (1970).

32 No hay una diferencia clara entre estos oficios y los de "alcaldes" y "tenientes" pues o bien se usaban indistintamente o se confundían.

33 Nos referimos sobre todo a Castilla, ya que en provincias como Vizcaya continuaron siendo electos hasta el siglo XIX. Ver MARTíNEZ RUEDA, F. (1994), p. 43

34 TOMÁs Y VALIENTE, (1976) y (1977); CUARTAS RiVERO, M. (1983) y (1984).

35 Cebreiros Álvarez, E. (1999), p.190 y ss.

36 Los jurados eran elegidos por los vecinos agrupados por barrios y su función era actuar al lado del alcalde forero en defensa de los intereses del pueblo. Sus atribuciones eran de índole judicial, fiscal, político-administrativo y de representación de la comunidad frente a otras instancias. El prestigio y el poder que conllevaba el cargo de jurado eran menores que el de regidor, por lo que se rebajaron los requisitos para su acceso y se permitió que lo ostentasen personas con patrimonios medios o con ambiciones de prestigio social. WEBER, M. (1944), p. 140 y ss.

37 El capitán general era uno de los cargos más apetecibles e influyentes ya que acumulaba la mayor parte del poder público en sus diversos ámbitos: militar, civil y judicial. El capitán general pasó a presidir la Audiencia, una especie de tribunal consultivo, excepto en los casos de administración de justicia donde la Audiencia era presidida por una autoridad civil. 
En la instalación del intendente en España se detectan dos momentos diferenciados: los años de la Guerra de Sucesión cuando Felipe $\mathrm{V}$ nombró en el territorio que controlaba a varios superintendentes del ejército con competencias fiscales, policía, justicia y guerra ${ }^{38}$ y un segundo momento, con la promulgación del Decreto del 4 de julio de 1718, por el cual se crean los “Intendentes de provincia y ejército" 39 supeditándolos directamente al Rey ${ }^{40}$.

Los intendentes se generalizaron y consolidaron con la Ordenanza de 13 de octubre de 1749, que supuso el establecimiento de las intendencias en toda España, con atribuciones de justicia, abastecimientos, policía, hacienda y militares. Fue precisamente la falta de especialización y las enormes competencias de las que fueron dotados, las que les ocasionaron numerosos enfrentamientos con los corregidores, el Consejo de Castilla o a los propios jueces y obligaron a Carlos III a promulgar la Real Cédula del 13 de noviembre de 1766, en las que le limitaba sus competencias a Hacienda y Guerra.

Las reformas administrativas borbónicas del siglo XVIII produjeron también la consolidación de la provincia como división económica ${ }^{41}$ y como territorio con una determinada jurisdicción político-administrativa, donde confluían los intendentes, los corregidores, el capitán general y otras unidades más pequeñas como "los partidos", "las hermandades", "los sextos" o "las islas". Estas reformas supusieron la consolidación definitiva del corregidor castellano al frente de todos los municipios del reino y la profesionalización del cargo ${ }^{42}$. La Real Cédula del 21 de abril de 1783 configuró un corregidor moderno, profesional y burócrata del que los reyes absolutistas no prescindirían, y que los liberales más moderados intentarían recuperar cada vez que accediesen al poder ${ }^{43}$.

El siglo XVIII supuso también la consagración del regimiento como forma de gobierno municipal, presidido por el corregidor y formado por alcaldes mayores y los tenientes de alcalde. Los primeros continuaron como ayudantes del corregidor, profesionalizados, especializados en determinadas materias administrativas y dotados de una escala de ascensos semejantes a la de sus jefes ${ }^{44}$. Los segundos por su parte constituían una entidad intermedia entre los alcaldes y los regidores que colaboraba en las tareas de gobierno y sustituía al alcalde en casos de necesidad. La base del regimiento la constituían los regidores y los jurados, pero desde el siglo XVIII se percibe una clara preeminencia de los primeros al hacerse con el poder de adjudicación de los servicios públicos ${ }^{45}$. Sin embargo existía una gran diversidad de funcionamiento de los municipios y cada uno contaba con reglas propias sobre el número de regidores y jurados, su extracción social y su funcionamiento interno ${ }^{46}$.

La crisis política de 1766 y las revueltas sociales de 1760-65 originadas por la pérdida de las cosechas, conllevaron grandes cambios para la administración municipal. El desabastecimiento agravado por la libertad de precios establecida por el Marqués de Esquilache, provocó la movilización ciudadana exigiendo la caída de éste y una serie de medidas económicas encaminadas a controlar los precios y abastecer los mercados ${ }^{47}$. El monarca Carlos III promulgó entonces el Auto Acordado de 5 de mayo de 1766, cuya principal innovación era la creación del síndico personero y del diputado del común ${ }^{48}$. El establecimiento de estos cargos trataba de garantizar un mejor

38 Concluida la Guerra de Sucesión, el intendente se fue generalizando a todas las provincias al tiempo que fueron aumentadas sus funciones incluyendo la administración de justicia en la que compartía jurisdicción con las audiencias, chancillerías y demás tribunales; la fiscalidad tanto para recaudar como para administrar impuestos. Además contaba con competencias militares, de policía urbana.

39 DOMínGUez ORTIZ, A. (1984).

40 Recordemos que los gobernadores en cuanto se generalizaron fueron nombrados por los Consejos y controlados por éstos. La creación de la nueva figura y su supeditación directa al poder real les restaba competencias y no les permitía intervenir en sus gestiones.

41 Con este carácter existía la provincia desde el siglo XVI pero no se podía hablar de administración provincial hasta los Decretos de Nueva Planta de Felipe V. Ver GARRıGós PICO, E. (1982). Este autor liga el origen de la provincia al servicio de Millones impuesto a la Corona de Castilla y que era dividido en unidades territoriales con voto en Cortes. Estas unidades permanecieron invariables hasta 1623 cuando se incorporaron dos nuevas provincias: Galicia y Palencia, que hasta entonces estaban incorporadas a Zamora y Toro respectivamente en la representación en Cortes.

42 GUILLAMÓN, J. (1988) (1990).

43 Los corregimientos pasaron a estar divididos en tres clases con distinta remuneración (entrada, ascenso y término), que los titulares debían recorrer en ese orden pasando de una a otra por antigüedad y méritos. Cada etapa era de 6 años y a su término se pasaba a las audiencias chancillerías, en el caso de los "corregidores de letras" y en el caso de los de "capa y espada" se le buscarían salidas para su carrera.

44 Marina Barba atribuye la unificación de los alcaldes mayores en 1763, a la necesidad de reducir los gastos de la administración y potenciar la consideración social del cargo. Ver MARINA BARBA, J. (1992), p. 42.

45 El ejercicio de las regidurías deparaba honor, poder y rentabilidad. Ver BARREIRO; MALLón, B. (1990). El oficio estaba dotado de competencias amplias que iban desde los abastos, hacienda, obras públicas, beneficencia, orden público, etc. Para subastar los abastecimientos se hacía un sorteo denominado "suerte del cántaro" porque se metían los nombres de los regidores y jurados en un cántaro y en otro los nombres de los oficios disponibles y se iban sacando ambos al tiempo. En estos sorteos, eran normalmente los regidores los que conseguían hacerse con los mejores puestos.

46 Algunos eran vitalicios, otros elegidos cada año, otros heredaban el cargo. En cuanto a procedencia unos eran nobles, otros profesionales liberales y aunque pocos, algunos procedían de profesiones manuales, etc. Sobre esto tenemos; BERMúDEZ AZNAR, A. (2003), p. $27-46$.

47 Las medidas de Esquilache provocaron el acaparamiento de grano por parte de los mercaderes en sus almacenes esperando sacarlos al mercado en un momento de desabastecimiento a precios exorbitantes. El hambre provocó los motines y el Rey tuvo que huir y refugiarse en Aranjuez y la presión popular no cesó hasta que se atendieron sus problemas.

48 La Instrucción del Consejo del 16 de junio de 1766 se refería al Auto y declaraba su obligatoriedad. 
suministro de los pueblos y una mayor colaboración con el corregidor y las restantes autoridades locales, las cuales se habían mostrado ineficaces, tanto en la prevención de motines como en la garantía de los abastecimientos. Ambos cargos eran elegidos mediante un sistema de elección indirecta donde todos los vecinos divididos en parroquias o barrios ${ }^{49}$, votaban a un determinado número de comisarios electores ${ }^{50}$, para que éstos, reunidos en el Ayuntamiento, designasen al diputado del común y al personero.

El síndico era un cargo de representación ciudadana, sin derecho a voto y cuyas únicas atribuciones eran el debate y envío de propuestas al Ayuntamiento, sirviendo de cauce entre esta institución y la población a la que representaba. Una vez creada esta figura, los jurados quedaron como obsoletos e ineficaces, aunque en la mayor parte de las poblaciones continuaron existiendo. Poco a poco los síndicos verán ampliadas sus competencias: asistencia con derecho a voto en las juntas locales de propios y arbitrios; el ejercicio de las facultades propias del oficio de almotacén; el voto con los regidores en la exacción de penas, suspensión y nombramientos de los oficiales que manejan los caudales de comunes o abastos y participación en los alistamientos de quintas.

Los diputados del común eran los representantes del pueblo y aunque contaban con derecho a voto, tan solo podían asistir a aquellas sesiones en las que se fueran a tratar cuestiones relacionados con los abastos. Cada pueblo tenía derecho a tener dos diputados del común, a excepción de los que contasen con más de 2000 vecinos donde habría cuatro51. Ambas instituciones se elegían anualmente, pero en 1769 los diputados del común pasaron a ocupar el cargo durante dos años, renovándose anualmente por la mitad para facilitar el conocimiento de los asuntos en los que tenían que actuar.

El comportamiento de estos cargos no fue uniforme en todo el territorio, y así mientras Marina Barba demuestra que en Granada las elecciones de estos nuevos oficios no interesaban a la mayor parte de los vecinos, lo que redundaba en una gran abstención y en la concentración de voto en dos o tres candidatos ${ }^{52}$. En cambio, Cebreiros Álvarez en su estudio sobre el Ayuntamiento de Santiago, demuestra que las elites locales trataron de controlar en todo momento estos oficios municipales ${ }^{53}$. Sea como fuere, en la mayor parte de los casos, los elegidos pertenecían a las clases medias, enriquecidas por los negocios industriales y comerciales, pero sin prestigio social ni poder político, que les permitiese ocupar otros oficios más estimados ${ }^{54}$.

A raíz de los motines de 1766 también se crearon los alcaldes pedáneos, que se revelarán como figuras importantes para el funcionamiento del municipio aunque su existencia apenas ha interesado a historiadores y administrativistas. La primera vez que son instituidos, será en Madrid por Real Cédula del 6 de octubre de 1768 para agilizar el funcionamiento de la justicia y ejercer un control de la población que permitiese evitar problemas de orden público como los que se habían producido. En 1769 la medida se extendió a todas las ciudades dotadas de chancillerías y audiencias y poco a poco al resto de municipios. Las atribuciones de estos alcaldes pedáneos eran de control de la población, alumbrado, limpieza y recopilación de datos sobre los habitantes de su barrio. Estos cargos tenían un marcado carácter judicial y no tanto gubernativo, trabajando siempre bajo la jurisdicción de las audiencias y las chancillerías. En el siglo XIX se recuperó esta figura con importantes modificaciones en sus atribuciones y dependencias, pasando a ser una un cargo gubernativo y administrativo supeditado al Ayuntamiento.

\section{LAS BASES TEÓRICAS DE LA ADMINISTRACIÓN LIBERAL}

Concepción de Castro plantea la posible existencia de tres modelos de administración liberal entre 1812 y 1868 aunque advierte que generalmente estos modelos respondían más a la aplicación de distintos presupuestos de partida, como los vistos en el análisis de Martínez Marina o Manuel Colmeiro, que a discrepancias fundamentales ${ }^{55}$.

Desde nuestro punto de vista, las diferencias más claras entre las políticas moderadas y progresistas se encuentran en las elecciones y en el modelo administrativo municipal. En la vertiente electoral los liberales más progresistas se distinguieron por conceder el derecho al voto a sectores tradicionalmente excluidos del poder

49 Para Domínguez Ortiz este hecho significaba la recuperación del Concejo Abierto, DomínGUEZ (1984). La instrucción que hablaba del proceso de elección era la Instrucción del Consejo del 26 de junio de 1766.

50 En el caso de existir una única parroquia se elegía a 24.

51 El Auto Acordado del 5 de mayo de 1766 permitió que los pueblos de menos de 2.000 vecinos eligiesen 2 síndicos y los que superasen esa cifra eligiesen a 4 síndicos.

52 MARINA BARBA, J. Poder municipal y reforma en Granada durante el siglo XVIII. Granada, Universidad de Granada, 1992, p. 149.

53 Cebreiros nos cuenta como el alcalde de Santiago, Bernardo de Ron en 1798 se quejaba de que en las elecciones de diputados del común y sindico personero, bastaba que una docena de "capataces" alzasen el grito en una asamblea popular para que se eligiese a determinada persona. CeBreIRos Álvarez, (1999), p. 213.

54 Son normalmente los comerciantes, industriales y profesiones liberales con "don" reciente los que forman las clientelas y piden el voto para ellos. De momento no hay demasiados estudios que avalen esta hipótesis pero es posible que los cargos de síndico y diputado del común fuesen desempeñados por una nueva clase profesional emergente, que los utilizaba de trampolín para acceder al poder municipal, debido a que los demás cargos les estaban vedados

55 DE CASTRO, C. (1979), p. 121-126. 
político y que fueron aprovechados en muchos pueblos para participar en las políticas públicas y hacerlas muy distintas a las moderadas. Estos liberales trataron de simplificar el gobierno municipal dotarlo de mayor consenso entre la población a través de la elección de los regidores en juntas parroquiales. El proyecto moderado se caracterizaba, en cambio, por la recuperación de políticas, estructuras y oficios del Antiguo Régimen, a los que dotaba de nuevas formulaciones y competencias para adaptarlos a la filosofía liberal, pero, tras los cuales, subyacía una misma preocupación por el control municipal.

Las grandes semejanzas entre ambas familias liberales, tenía su origen en la existencia de un tronco doctrinal común inspirado en la llustración y en el modelo administrativo local francés ${ }^{56}$. Así, al hablar del modelo liberal es necesario buscar las raíces del mismo en los distintos modelos que le sirvieron de inspiración y uno de ellos fue el Estatuto de Bayona de 1808 y las leyes de José Bonaparte. Tras la invasión de 1808, los franceses trataron de construir una administración funcional basada en comisarios regios que controlaban el gobierno local y la creación de ayuntamientos como el de la municipalidad de Madrid (Decreto del 21 de agosto de 1809) dotado de un corregidor, 16 regidores, un procurador del común y varios oficios administrativos ${ }^{57}$. Este modelo tenía como objetivos principales erradicar las ventas de los cargos concejiles, estableciendo que los regidores fuesen elegidos entre los vecinos propietarios y democratizar el funcionamiento de los municipios al atribuir al ayuntamiento las decisiones gubernativas ${ }^{58}$. Este fue el modelo que los franceses en su siguiente Decreto del 4 de septiembre de 1809 intentaron generalizar a todos los municipios del territorio que dominaban ${ }^{59}$, pero fue también la base que los liberales de Cádiz tuvieron presente para legislar sobre los nuevos municipios que querían instalar ${ }^{60}$. Su característica principal era la centralización ${ }^{61}$ y la ruptura que producía en la tradición de patrimonializar los oficios $^{62}$.

La marcha de los franceses y las Cortes de 1812 constituyeron el punto de partida para la modernización administrativa española, aunque no sin grandes debates intrínsecos al liberalismo en los que terminó dominando la vía más conservadora. Los liberales más avanzados, inspirados por la revolución francesa, trataron de instalar un modelo descentralizador en el que los pueblos gestionasen sus propias necesidades ${ }^{63}$ y contasen con una administración política lo más participativa posible. Por su parte, el ala más conservadora del liberalismo era partidaria de fijarse también en Francia pero no tanto en la revolución sino más bien en la restauración borbónica y en la producción doctrinal que se produjo entre 1817 y 1848 sobre la mejor forma de gobierno aplicada al territorio ${ }^{64}$. El modelo administrativo resultante sería el conocido como modelo doctrinario y que Sánchez Agesta definió como

56 GARcía FERNÁNDEZ, J. (2003), p. 47 y ss.

57 García Fernández esquematiza la influencia napoleónica en los cargos municipales de la siguiente manera: el alcalde estaría configurado en la Constitución de 1812 según la influencia de la Novísima Recopilación y la Ley del 28 de Pluvioso del año VIII; los jefes políticos, Diputaciones provinciales como órganos tutores sobre los ayuntamientos vendría de la Ley Francesa del Año VIII; el sistema electoral tendría su origen en las reformas de Carlos III combinadas con la ideología democrática liberal de las Cortes de Cádiz. Ver GARCía FERNÁNDEZ, J (1976).

58 Aunque el gubernativo estaba en manos del Ayuntamiento, las asambleas abiertas en las que participaban únicamente los propietarios, no desaparecieron del todo sino que la nueva legislación contemplaba su reunión para casos muy concretos de interés municipal y para la elección de los candidatos para las Juntas Generales de Prefactura y subprefectura.

59 De Bernardo ARES, J.M. (1989), p. 653 y ss.

60 Este Decreto titulado "Para la Creación de nuevas municipalidades en todo el Reyno y obligación que se impone a los jueces, abogados y escribanos de presentar sus títulos" disolvía los antiguos ayuntamientos dando por nulos sus actos y acuerdos y ordenaba la creación de unos nuevos. El Decreto del 17 de abril de 1810 establecía la división territorial del país en 38 Prefacturas que se subdividían en Subprefecturas y estas en unidades más pequeñas que eran las Municipalidades. Hay que tener en cuenta que municipalidad era la traducción al español de la palabra francesa "comuna" y se instauró esta palabra a pesar de existir la palabra española "municipio".

61 La centralización se hacía a través del Prefecto que asumía todos los poderes ejecutivos de los pueblos y los consejos de prefectura que eran los encargados de conocer instructiva y gubernativamente todos los asuntos municipales autorizando las gestiones. Se les reservaba a los ayuntamientos pues un poder ejecutor.

62 El estudio del profesor Miguel Artola sobre los afrancesados es referencia básica para comprender la presencia de los franceses en España. Ver ARTOLA, M. (1989).

63 El fruto de sus argumentos fue la mención en el artículo 321 de la Constitución de 1812 que las personas de los pueblos eran las que mejor conocían las necesidades y problemas de éstos y por lo tanto eran los más adecuados para gobernarlos. Más tarde, la Constitución de 1837 (Art. 70) a raíz de esta línea de pensamiento, reconocía que existían una serie de atribuciones específicas que le correspondían a los pueblos y que los mismos tenían una base electiva. GARCía DE ENTERRíA, E. (1981).

64 Destacó en esta línea ideológica, Henrion de Pansey, un jurista especializado en derecho feudal, que publicó en 1820 "Du pouvoir municipal et la police intérieure des comunes". También, Barante con su obra publicada en 1821 "Des comunes et de laristocratie" y también Vivien, que en 1845 publicó “Études administratives" con cuatro capítulos dedicados a administración local.;

En la historia política tiene un sitio destacado el "partido de los doctrinarios", de corte monárquico-constitucional, que surgió en la Francia de la Restauración de Luis XVIII. Sus representantes son P. P. Royer Collard, F. P. G. Gizot, P. F de Serre, J. C. Beugnot, P. de Barante y D. Jordan. Aunque el número era restringido se caracterizaban por su heterogeneidad aunque su línea básica era el constitucionalismo en el que se garantizase el orden público. Desde 1814 incluyeron entre sus presupuestos la "Carta Octroyée" que garantizaba la igualdad ante la ley, libertad de conciencia y de prensa, la abolición del régimen feudal, etc. El poder ejecutivo se dejaba en manos del Rey y el legislativo se lo repartían dos cámaras, una de designación real y carácter hereditario a la que se le denominaba "Cámara de los pares" y otra denominadaza "Cámara de representantes" elegidos por sufragio censitario. 
un modelo de representación de unos pocos que se autodefinía como doctrina racional y práctica ${ }^{65}$. Fernández Cuesta lo definió como vía intermedia entre el liberalismo progresista y el tradicionalismo más acusado ${ }^{66}$. Ortega y Gasset lo defendió diciendo que era "Io más valioso que ha habido en la política del continente durante el siglo XIX"67. Podríamos seguir citando numerosas definiciones de doctrinarismo tanto de intelectuales del siglo XX como de los contemporáneos del siglo XIX ${ }^{68}$, pero lo que más nos interesa es saber cuales de sus formulaciones administrativas fueron aplicadas en la instalación de la administración local española ${ }^{69}$.

Los doctrinarios concebían al municipio como un peldaño de la administración sometida a los principios de mandato representativo garantizado por un censo de riqueza con distintas cuotas según el tamaño. La teoría doctrinaria sobre la organización municipal se conoce como "Pouvoir municipal", caracterizándose por los principios de representatividad, centralización y separación de competencias entre las propias del municipio y las que les concedía el Gobierno ${ }^{70}$. La separación de competencias entre propias y delegadas fue una innovación de los doctrinarios y se trasladó directamente al modelo municipal liberal moderado creado a partir de la Constitución de 1845 y la Ley de Ayuntamientos del 8 de enero de 1845. El doctrinarismo fue también decisivo en las figuras gubernativas con autoridad en el término municipal que fueron creando los distintos gobiernos moderados y de la Unión Liberal71.

\section{LA ADMINISTRACIÓN LIBERAL}

La instauración del liberalismo y la Constitución de 1812 eliminaron el viejo sistema de consejos, subsistiendo únicamente el Consejo de Estado ${ }^{72}$ a la vez que otorgaron a los secretarios de despacho poderes similares a los ministros actuales confiándoles la administración del Estado ${ }^{73}$. En lo referente a los municipios, se recogía la necesidad de subdividir el territorio en unidades administrativas más pequeñas denominadas provincias, pero sin determinar sus características ni sus límites ${ }^{74}$. La vuelta de Fernando VII dejó el proyecto en el aire al reinstaurar las intendencias, pero en 1820 se recuperó la idea y se aprobó la división del territorio español en 52 provincias ${ }^{75}$.

El Decreto del 23 de junio de 1813 y la Instrucción del 3 de febrero de 1823, considerada la primera ley municipal y provincial del siglo XIX, extendían al ámbito local la separación de poderes y otorgaban mayor capacidad de decisión a los órganos colegiados sobre los unipersonales ${ }^{76}$. En este sentido se desarrollaron los poderes de las diputaciones provinciales ${ }^{77}$, otorgándoles facultades de decisión en expedientes de establecimiento y supresión de los ayuntamientos, repartos de contribuciones y resolución de quejas sobre los mismos y la supervisión de los temas presupuestarios y fiscales de los ayuntamientos que controlaban. Se le concedió también la organización de la Milicia Nacional y la instrucción pública, la beneficencia y el fomento de los pueblos ${ }^{78}$.

65 SÁNCHEZ AGESTA, L. (1984).

66 FERNÁNDEZ-CUESTA Y MERELO, R. (1976), p. 79-91.

67 ORTEGA Y GASSET, (1966), p. 19.

68 Adolfo Posada definía el doctrinarismo político como: "puede considerarse el llamado doctrinarismo político como un intento, enderezado a armonizar o componer los principios de la Revolución y los del Tradicionalismo monárquico, con legitimidad o no”. PosADA, A. (1935), pp. 401-402.

69 Los doctrinaristas predominaron en Francia durante toda la Restauración y la monarquía de Luis Felipe. Su teoría era que puesto que era imposible volver a ejercer el poder absoluto, debía darse un Pacto entre la nueva clase burguesa ascendente que se había adueñado del Parlamento y la vieja aristocracia que se había quedado sin el poder tras la caída del Antiguo Régimen. Ese Pacto reconocería la legitimidad de la burguesía en el Parlamento siempre que se le permitiese a la Aristocracia detentar el poder municipal. En España se adoptaron estos presupuestos teóricos a partir de la Constitución de 1837 y ese influjo es visible en políticos como Javier de Burgos y en sus ideas administrativistas, en Posada Herrera, Joaquín María López, Gómez de la Serna, Oliván, etc.

70 La teoría doctrinaria sobre la administración local fue expuesta por Royer-Collard en la Cámara francesa en 1819 y de ella se desprende una concepción del municipio como ente anterior al Estado, al igual que la familia y a las leyes.

71 Según Sarmiento Larrauri el pensamiento doctrinario solo se aplicó en España en el período comprendido entre 1833 y 1836 y más tarde entre 1843 y 1854 . Su pensamiento se plasmó únicamente en el Estatuto Real y en la Constitución de 1845. Ver SARMIENTO LARRAURI, J. I. (1993), p. 149.

72 Pasó a llamarse Consejo del Rey y este debía oírlo en asuntos importantes.

73 La nueva legislación implicaba que todas las órdenes del Rey debían ir firmadas por los secretarios de Despacho y además se les atribuyó el "principio de responsabilidad" sobre cualquier orden que en adelante diesen. Estas son las características que los hacen asimilables con los ministros actuales.

74 Art. 11 de la Constitución de Cádiz. "Se hará una división más conveniente del territorio español por una ley constitucional, luego que las circunstancias políticas de la Nación lo permitan”.

75 Decreto de 27 de enero de 1822. Su vigencia fue corta, desapareciendo al finalizar de forma violenta el Trienio.

76 Posada destacaba como factores principales de esta nueva ley la caracterización de los ayuntamientos y las Diputaciones provinciales como organismos deliberantes y de base corporativa, los alcaldes y jefes políticos como organismos unipersonales de carácter ejecutivo y la función ejecutiva y administrativa de los ayuntamientos basados sobre todo en la índole personal. POSADA, A. (1910).

77 El artículo 325 de la Constitución de Cádiz determinaba la instalación de una Diputación en cada provincia, presidida por un Jefe Político para el cumplimiento de funciones amplias como informar sobre la formación de los nuevos ayuntamientos liberales, la repartición de contribuciones, la conservación de las infraestructuras y la autorización de la imposición de arbitrios para estas necesidades. Estas Diputaciones estaban formadas por el Jefe Político como presidente, el Intendente de la Provincia y siete individuos elegidos sin perjuicio de que las Cortes pudieran variar el número o lo exigieran la división provincial. Se renovaba este organismo cada dos años.

78 Posada HeRrera, J. (1988). 
A pesar de la preferencia por los órganos colegiados, se decidió mantener un órgano unipersonal con poderes suficientes para representar al Gobierno en las provincias, y así se fue configurando al jefe político. El jefe político actuaba como presidente de la diputación, garantizando el cumplimiento de sus obligaciones ${ }^{79}$ y supervisando el funcionamiento de los establecimientos públicos. Como representante del Gobierno en la provincia, transmitía las órdenes a los pueblos de su área de influencia, garantizaba el orden público, el control de la población, la sanidad y la higiene y fomentaba el desarrollo económico ${ }^{80}$. En lo referente a los ayuntamientos, contaba con facultades para su nombramiento y podían presidir sin voto el ayuntamiento en el que residían y cualquier otro de su provincia donde se encontrasen de viaje. Además, fiscalizaban las cuentas de los municipios, sus elecciones y cualquier decisión política que pudiesen hallar de su incumbencia.

El último peldaño de la administración local lo constituían los ayuntamientos y aunque se realizó una configuración territorial totalmente nueva, la recuperación de viejos cargos, ensombreció la novedad del esquema administrativo. La organización municipal quedó unificada y organizada a través de varios decretos: el del 23 de mayo y 10 de julio de 1812 y el del 13 de junio de 1813 , mediante los cuales se asignaba un número de alcaldes ${ }^{81}$ y regidores en relación a la población y se establecía un sistema electoral en el que para participar era necesario ser mayor de 25 años y contar con al menos 5 años de residencia. La duración del cargo era de dos años renovándose por la mitad cada año y su desempeño era obligatorio.

La Instrucción del 23 de junio de 1813 determinó las atribuciones asignadas a las entidades locales, pero además aportó como gran novedad la distinción entre competencias propias del Ayuntamiento y competencias delegadas ${ }^{82}$. En las competencias delegadas actuaba a las órdenes y en nombre del Gobierno y entre las propias contaba con atribuciones como el saneamiento de calles y establecimientos, el control de enfermedades ${ }^{83}$, el ornato público, etc.

La vuelta de Fernando VII suspendió toda la actividad local hasta que el levantamiento de Riego en Cabezas de San Juan, no solo dio comienzo al Trienio Liberal y la reinstauración de la Constitución de 1812, sino que situó a los ayuntamientos como auténticos protagonistas del cambio político. El brazo armado de los ayuntamientos liberales fue la Milicia Nacional y su instrumento legal fue la Instrucción de 1813, hasta que el propio gobierno liberal se dio cuenta de la necesidad de producir una nueva norma municipal que reglamentase su poder ${ }^{84}$.

La Ley de 3 de febrero de 1823 fue considerada la primera Ley de Régimen Local de la historia de España. En su elaboración hay que destacar no sólo el enorme trabajo de los diputados recopilando y revisando los textos legales anteriores a la Instrucción de $1813^{85}$, sino también el interés de los progresistas en asentar sus bases sociales sobre las clases populares ${ }^{86}$ de las ciudades.

Los dos temas entorno a los que gira esta ley serán el mayor grado de participación electoral al rebajar la base económica para ser elector y elegible y el mayor grado de autonomía y competencias concedidas al sistema local. La nueva ley tomó como punto de partida la diferenciación entre competencias propias de los ayuntamientos y competencias delegadas por el gobierno, aumentando mucho las primeras para potenciar la autonomía municipal. Las materias consideradas propias abarcaban temas de higiene, infraestructuras locales, sanidad, beneficencia y también los abastecimientos que constituían el gran caballo de batalla no solo por su enorme complejidad, sino porque su mal funcionamiento podía provocar carestías y apartar a los a los liberales del poder. Las atribuciones delegadas se limitaron a funciones de control policial, como la elaboración de censos y registros civiles, la construcción de obras públicas, el cuidado de montes y de propios, la administración y recaudación de fondos públicos y por último, las tareas relacionadas con el ejército, tanto la elaboración de quintas como alojamientos y bagajes.

79 En concreto en 1813 se estableció una legislación tendente a que los negocios de aprobación de cuentas y repartimientos de contribuciones la responsabilidad del acuerdo recaía en toda la Diputación, mientras que en los negocios de cuidar o promover asuntos de bien público la responsabilidad recaía solo en el jefe político.

80 RUEDA HERRANZ, G. (2008), p. 72-84.

81 Recordemos que los moderados serán partidarios de un único alcalde por ayuntamiento y así lo harán en 1845

82 PAREJO, A. (1988). Este autor atribuye esta distinción de competencias a la adopción del sistema revolucionario francés. Para García Fernández en cambio la relación de competencias no tendría un orden determinado ni un precepto que las delimitase, ni aparecería clara su origen aunque estaría bastante cercano a la Novísima Recopilación. Ver GARCíA FERNÁNDEZ, J. (1983).

83 La falta de competencias de los ayuntamientos para actuar inmediatamente una vez que se detecta la penetración de una enfermedad como el cólera o la viruela facilitará la extensión del cólera en 1833 en Galicia. Los ayuntamientos antes de actuar tenían que remitir un informe a su jefe político y éste era el que autorizaba o no la toma de medidas y el presupuesto disponible.

84 El 3 de febrero de 1823 surge el Decreto llamado “Instrucción para el Gobierno Económico-Político de las Provincias" que había sido presentado en la legislatura de 1822. Fue sancionado por el Rey el 2 de marzo de 1823 y aunque solo estuvo vigente unos meses, fue recuperado el 15 de octubre de 1836 hasta el 30 de diciembre de 1845 y reestablecido el 7 de agosto de 1854 hasta el 5 de julio de 1856.

85 El primero que lo definió así fue Adolfo Posada y desde ahí los administrativistas han estado de acuerdo en esta valoración.

86 Ver LIDA, C.E. (1997), p. 4 y ss. 
En el esquema gubernativo municipal se hizo hincapié en la figura del alcalde ${ }^{87}$ asignándole competencias propias del ejecutivo municipal y otras otorgadas por delegación del gobierno estatal fiscalizadas por el jefe político. El alcalde contaba con iniciativa propia en orden público y en la ejecución de disposiciones y acuerdos municipales, y aunque podía pedir consejo a la Corporación, también podía actuar al margen de la misma ${ }^{88}$. En el campo jurisdiccional se recortan aún más sus atribuciones, permitiéndole incoar las primeras diligencias y remitirlas a los jueces competentes con el debido informe y también el arbitraje previo a la tramitación de expedientes ${ }^{89}$. En los demás ámbitos dependía del jefe político, correspondiéndole temas relacionados con la Milicia Nacional9 ${ }^{90}$, el ámbito contencioso-administrativo91, el orden público y control policiala2.

La Ley del 3 de febrero de 1823 distinguía perfectamente entre competencias de gobierno y la ejecución de las decisiones políticas. Así, dejaba en manos del alcalde y del jefe político la ejecución de las decisiones que eran tomadas y aprobadas por mayoría en los órganos colegiados de los ayuntamientos y las diputaciones ${ }^{93}$.

La muerte de Fernando VII en 1833 y los problemas sucesorios en la figura de la Infanta Isabel propiciaron que la Regente María Cristina otorgase un año después el Estatuto Real, para la supervivencia de la Corona y del régimen político en el que se venía apoyando. El sistema del Estatuto Real pivotaba sobre un reformismo técnico que pretendía dejar intactas las estructuras políticas reformando únicamente la economía y la administración ${ }^{94}$. Esta postura chocó con la de varios generales del ejército que exigieron a cambio de su apoyo a la causa Isabelina, verdaderas modificaciones políticas y sociales y obligaron a la Reina Regente a permitir dos hechos fundamentales: la sustitución del Gobierno ${ }^{95}$ y la instauración de un sistema parlamentario ${ }^{96}$. El Estatuto Real terminó siendo así, una solución de compromiso, en el que destacaban un sistema de cortes bicameral97, el sufragio censitario y la formación de partidos de notables ${ }^{98}$.

En este clima de reformismo político se planteó la necesidad de reformar la administración municipal para hacerla más eficaz y sobre todo para evitar que se convirtiese en foco de problemas para el nuevo régimen liberal. El encargado de la reforma fue Javier de Burgos, quien dividió el territorio español en 49 provincias ${ }^{99}$ y marcó para siempre con el Decreto del 30 de noviembre de 1833 la historia administrativa de España, no sólo porque en el futuro apenas se realizarían modificaciones en la estructura provincial, sino porque sentó las bases de una nueva forma de gobierno que perduraría mucho tiempo ${ }^{100}$.

87 Art. 183 de la Ley del 3 de febrero de 1823: “El gobierno-político de los pueblos (que) estará a cargo del alcalde o alcaldes de ellos, bajo la inspección del Jefe Político superior de la provincia".

88 Artículo 191 de la Ley del 3 de febrero de 1823,“

89 El Art. 200 le permitía practicar las primeras diligencias en caso de delito, el 201 ser órgano de conciliación.

90 Art. 195.

91 Si un vecino resultaba agraviado por una decisión del alcalde podía recurrir ante el Jefe Político para que este resolviese de inmediato, pues era este y no los tribunales los que se encargaban de resolver estos problemas. Ver artículos 209-211.

92 El artículo 194 le permitía expedir pasaportes, el 197 responsabilizarse de las tareas relacionadas con el ejército, el 198 perseguir delincuentes, etc.

93 En este hecho abunda Garrido Muro, al considerar que la Instrucción del 23 de junio de 1813 para el gobierno económico-político de las provincias y después la Ley del 3 de febrero de 1823: "abundaban en la misma línea al comprender toda la administración económicoadministrativa del territorio a su cargo, sin vigilancias ni tutelas". GARRIDO MURO, L. (2006), p. 210.

94 El reformismo consiste también en superar la concepción de la monarquía como "sola y pura" a favor del establecimiento de una “monarquía Constitucional" aceptable para la Corona.

95 Cesó al claramente absolutista Cea Bermúdez y lo sustituyó por Martínez de la Rosa, más grato a los liberales.

96 El Estatuto Real se caracterizaba por no llegar a ser una Constitución pero tampoco era una Carta otorgada, sino un sistema híbrido en el que predominaba claramente la monarquía sobre las otras instituciones de Gobierno. Fue promulgado el 19 de abril de 1834.

97 Las Cortes se componían de un estamento de próceres del reino y otro estamento de procuradores del reino. El primero lo componían de forma vitalicia las dignidades de la nación (obispos, arzobispos y grandes de España como miembros natos) y una serie de miembros nombrados por el Rey entre la nobleza de Castilla, servidores de la Administración, embajadores, etc. siempre que tuviesen una renta superior anual a $60.000 \mathrm{r}$. El estamento de procuradores, era la cámara electiva y por la cual se colmaban las aspiraciones de apertura política de los liberales y se necesitaban una renta anual de $12.000 \mathrm{r}$.

98 El término "notable" ha sido empleado por Jesús Cruz, Isabel Burdiel, etc. Se refiere a un grupo de personas procedentes de las viejas oligarquías agrarias y administrativas y burgueses de riqueza joven, que ostentan una posición de dominación social basada en el patronazgo y puestos políticos derivados de su riqueza pero también de elementos tradicionales como eran el reconocimiento y el prestigio social. BURDIEL, I. (1996), pp. 123-138; CRUZ, J. (2000), p. 280 y ss.

99 Los nombres de estas serían los de sus capitales respectivas, excepto Navarra. El Real Decreto de Fernando VII del 1 de octubre de 1823 ordenaba la vuelta por segunda vez al Antiguo Régimen suspendiendo en consecuencia los ayuntamientos constitucionales. A raíz de ello el proceso de instalación de ayuntamientos en 1833 tuvo que partir de cero y dividir primero el país y en segundo lugar crear nuevas figuras administrativas. Desde este momento la secuencia legislativa es la siguiente: el 15 de octubre de 1836 se restablece la Instrucción de 1823 hasta el 11 de enero de 1845 aunque en el medio quedó el "Real Decreto del 16 de julio de 1835 para el Arreglo Provisional de los Ayuntamientos del Reino".

100 Javier de Burgos era un intelectual administrativista formado en la llustración y partidario de las reformas administrativas como fórmula de superación de los problemas políticos. Sus ideas quedaron bien claras en su "Exposición dirigida a S. M. el Sr. D. Fernando VII, desde París en 24 de enero de 1826 por Javier de Burgos", donde hacía una relación de los males que según él aquejaban al país y proponía una serie de reformas para solventarlos. Ver el estudio sobre la figura y la trayectoria de Javier de Burgos.,GAY ARMENTEROS, J. C. (1993). 
Las nuevas unidades administrativas creadas por Javier de Burgos estaban dotadas de competencias militares, judiciales y hacendísticas y eran dirigidas por un subdelegado de fomento ${ }^{101}$, cuyo control tendía a consolidar la nueva administración como centralizada, unificada y homogeneizada, dejando escaso margen a la autonomía municipal ${ }^{102}$. Sin embargo, hay que resaltar que aunque el subdelegado de fomento contaba con enormes poderes sobre su territorio, nunca tuvo tantas competencias como cuando fue reconvertido a jefe político en 1845 . El Decreto del 30 de noviembre definía a los subdelegados como "Jefe inmediato del Ayuntamiento", pero a efectos prácticos en los ayuntamientos no se le consideraba como tal y tan solo se le reconocían competencias sobre las elecciones y sus incidencias ${ }^{103}$.

El Decreto del 23 de julio de 1835 configuró los ayuntamientos de forma provisional, electiva y con voto censitario e indirecto ${ }^{104}$, a excepción de Madrid y otras capitales, que el Gobierno estimase conveniente ${ }^{105}$. Se estableció un único alcalde ${ }^{106}$, un síndico y cierto número de regidores y tenientes de alcalde proporcionales a la población. Los oficios no podían ser enajenados ${ }^{107}$, heredados o vendidos, aunque se pretendía, tratando de establecer un vínculo de continuismo con el Antiguo Régimen, indemnizar a los que eran propietarios de algún cargo concejil, para que devolviesen la propiedad de los mismos a la Corona ${ }^{108}$.

Dentro del ayuntamiento, la figura más importante era el alcalde, porque se le conferían todavía funciones contenciosas en pueblos donde no hubiese juez de primera instancia, para resolver asuntos civiles que no pasasen de 200 reales y en asuntos de injuria verbal con penas ligeras ${ }^{109}$. Cuando actuaban como jueces no dependían del subdelegado de fomento, sino que lo hacían de los tribunales correspondientes, continuando así como figura a medio camino entre el Antiguo Régimen y la época contemporánea. El resto de sus funciones eran de tipo gubernativo, sometiéndose a la autoridad superior provincial al igual que el ayuntamiento, al que se había vaciado de competencias ${ }^{110}$.

El 13 de agosto de 1836 se produce el Motín de la Granja que llevaría a los progresistas al poder y a la restitución provisional de la Constitución de 1812. En 1837 se promulga una nueva Constitución ${ }^{111}$, como punto consenso entre los liberales para hacer frente a la Guerra Carlista y a la crisis económica, hacendística, así como de instituciones como el ejército, al que no se le pagaba el sueldo desde hacía meses, o de la propia Corona ${ }^{112}$.

En lo referente a las entidades locales se restableció la legislación de Cádiz y del Trienio tratando de dar continuidad al apoyo de las clases medias y medio bajas que el liberalismo más progresista tenía en las ciudades. Por su parte los núcleos rurales continuaron dominados por los notables moderados, quienes supieron aprovechar la estancia del Conde de Ofalia en el Gobierno para tratar de reformar la ley de ayuntamientos en su favor. En 1838, los moderados presentaron un proyecto basado en la participación exclusiva de los mayores contribuyentes en la política local ${ }^{113}$, la intervención gubernamental en la designación de los alcaldes, la reducción de las competencias

101 GAY ARMEnTERos, J. C. (1993), pp. 123-124. Armenteros sostiene que Javier de Burgos cuando hizo su decreto no trató de imitar a la división provincial francesa, sino que recogía una larga tradición que venía de las Reformas de Carlos III en adelante y fijándose especialmente en las reformas de José I. Se apoya en que su división territorial recogía una doble tendencia desde el XVIII: el deseo de acoplar la estructura territorial a moldes más razonables y por otro lado la tendencia centralizadora.

102 Los Subdelegados de Fomento perviven y lo hacen porque la Ley del 2 de abril de 1845 y el Real Decreto del 29 de septiembre de 1847 se convierten primero den jefes políticos y luego en gobernadores civiles.

103 MONTANOS FERRÍN, E. (1992).

104 El cuerpo electoral estaba formado por españoles mayores de 25 años, con al menos cuatro años de residencia en la provincia y dos en el pueblo donde pagaba una cuota fija por sus actividades económicas. Para ser miembro del ayuntamiento era necesario lo mismo que para se elector pero además debía saber leer y escribir y estar incluido en las listas de mayores contribuyentes. El voto no era secreto sino que se ponía en las papeletas el nombre, dirección y firma del elector y lo mismo en caso de abstención.

105 En estos municipios, tanto el Ayuntamiento como el alcalde serían nombrados por el Rey.

106 En Cádiz se había adoptado la fórmula de pluralidad de alcaldes en función de la población.

107 El Decreto estipulaba claramente que los oficios de la república y sus dependencias son de elección libre. Ello venía a significar precisamente la supresión de todos los oficios que estaban enajenados desde épocas anteriores como el de regidor, jurado, alférez, veinticuatro, escribano, etc.

108 Nos remitimos a todo lo dicho anteriormente sobre el Ayuntamiento en la edad moderna y el siglo XVIII.

109 El alcalde tenía además facultades para imponer multas a los que faltasen a sus bandos o cometiesen desacato, pero siempre que no excediesen de 100 r. o tres días de arresto.

110 El alcalde tenía competencias para publicar y hacer cumplir las normas, convocar y presidir el ayuntamiento, protección de la seguridad y propiedad de los vecinos, orden público, sanidad, policía urbana, prevención de incendios, registros civiles, inspección y control de los empleados municipales y asuntos económicos del ayuntamiento, ejecutar acuerdos, hacer presupuestos y remitirlos al jefe provincial, creación o suspensión de establecimientos públicos, venta o permuta de fincas, etc.

111 La Corona aumentó mucho sus prerrogativas respecto a la Constitución de 1812. Se le contemplaba la soberanía compartida entre el Rey y las Cortes, cuando anteriormente solo sancionaba y además se le concedía el veto absoluto sobre una ley cuando en 1812 únicamente era suspensivo. Además de estas facultades se le adjudicarán otras como la inviolabilidad del Rey, convocatoria y suspensión del Congreso, etc.

112 Bahamonde, A. y MARtínez, J.A (1998); VARELA SuANZeS-CAMPEGNA, J. (1983-1984), p. 95-106.

113 El censo electoral sería configurado según una escala donde solamente tendrían derecho a voto todos los vecinos en aquellos pueblos de menos de 60 vecinos. En el resto de los pueblos era necesario para ser elector contar con más de 25 años y contribuir con grandes 
de los regidores hasta la mera deliberación, el alcalde como único poder ejecutivo dentro de los ayuntamientos por delegación del Jefe Político y lo que era más importante, la capacidad de éste último para destituir a todos los miembros del Ayuntamiento.

El proyecto de Ofalia no salió adelante ${ }^{14}$, pero las Cortes moderadas de 1840, lo retomaron, causando la ruptura total con los progresistas, que desde ese momento se movilizaron contra la ley de ayuntamientos que pretendían elaborar los moderados ${ }^{15}$. La situación de crisis absoluta hizo caer a la Regente, retornando los progresistas al poder entre 1840 y 1843 encabezados por el General Espartero, quien promulgó una versión modificada de la ley municipal de 1840 , lo que acabó por restarle apoyos entre sus propias filas y permitiendo el retorno de los moderados al poder en 1844 y la promulgación de la Ley de Ayuntamientos de 1845.

\section{BIBLIOGRAFÍA}

ALBI, F. (1943): El corregidor en el municipio español bajo la monarquía absoluta, Madrid.

GONZÁlez Alonso, B. (1970): El corregidor Castellano (1348-1808), Madrid.

Albornoz, C. (1976): "El gobierno de las ciudades de España del siglo V al X. Instituciones Económicas y Fiscales. Instituciones Jurídico Políticas”. En: Viejos y Nuevos Estudios sobre las Instituciones medievales españolas. Madrid, Espasa Calpe.

BAhAmonde, A. y MARTínez, J.A. (1988): Historia de España del siglo XIX. Madrid, Cátedra.

BARReIRo MALlón, B. (1990): “Estructura municipal de Asturias en el siglo XVIII”, en Coloquio Internacional Carlos III y su siglo. Actas, Tomo III, Madrid.

Bermúdez AznAR, A. (2003): "Marco jurídico del municipio en el transito del Antiguo Régimen al Estado Constitucional”, en Il Seminario de Historia de la Administración. El Municipio Constitucional. INAP, pp. 27-46.

BURDIEL, I. (1996): “Análisis prosopográfico y revolución liberal, 1834-1854”, Revista de Estudios políticos, № 93, pp. 123-138.

CASTILLO DE BOVADILLA (1750): Política para corregidores y señores de Vasallos, en tiempos de paz y de guerra y para juezes eclesiásticos y seglares y de sacas aduanas y de Residencias y sus Oficiales y para regidores y abogados y del valor de los Corregimientos y Goviernos Realengos y de las Ordenes. I. Amberes.

Cebreiros Álvarez, E. (1999): El municipio de Santiago de Compostela a finales del Antiguo Régimen (1759-1812), Santiago de Compostela, Xunta de Galicia.

Colmeiro, M. (1883): Cortes de los Antiguos Reinos de León y Castilla, Madrid.

CORRAL GARCía, E. (1988): Ordenanzas de los concejos castellanos, formación contenido y manifestaciones (siglos XIII-XVIII), Burgos.

CRUZ, J. (2000): Los notables de Madrid. Las bases sociales de la revolución liberal española, Alianza, Madrid.

CUARTAS RIVERO, $M$.

- (1984): “La venta de oficios públicos en Castilla-León en el siglo XVI”, Hispania, XLIV, pp. 495-516.

- (1983): "La venta de oficios públicos en el siglo XVI” IV Simposium de Historia de la Administración, Madrid, pp. 225-261.

cuotas según (en los pueblos entre 60 y 300 vecinos serían electores 180 personas, en los pueblos de hasta 1.000 vecinos solo 413 de ellos serían electores, en los de hasta 5.000 vecinos tendrían derecho a voto 1.413 personas, hasta 20.000 vecinos podrían votar 4.413 electores y por último en los de más de 20.000 vecinos podrían votar 4.414 electores más la sexta parte del número de vecinos que excedan el número de 20.000 ).

114 Los moderados ganaron las elecciones de 1837 pero no consiguieron la estabilidad en el gobierno y se sucedieron los equipos ministeriales durante estos años sin que ninguno encontrase la estabilidad. El primero de ellos fue Bardají hasta mediados de diciembre de 1837, se sustituyó Ofalia el 16 de diciembre hasta septiembre de 1838, Frías desde septiembre a diciembre de 1837 y por fin Evaristo Pérez de Castro consiguió ocupar el gobierno entre el 9 de diciembre de 1838 y julio de 1840. La razón de que el proyecto de Ofalia no fuese adelante fue precisamente por la inestabilidad política y el corto espacio de tiempo que estuvo en el poder.

115 Teniendo en cuenta los proyectos frustrados precedentes, el ministro Calderón y Collantes presentó su proyecto el 21 de marzo de 1840 sobre organización y atribuciones de las diputaciones y de los ayuntamientos. El proyecto fue presentado sin el apartado de las diputaciones y fue aprobado por mayoría de votos como ley municipal el 14 de julio de 1840 . Sin embargo, desde los primeros debates apareció el tema de la inconstitucionalidad de la ley, planteada por el diputado Cabello, que consideraba que la autorización solicitada por el gobierno a la monarquía para aprobar el proyecto no era legal. Durante la discusión del proyecto ley se volvió a plantear esta cuestión y más tarde el diputado Ayllón presentó el 6 de abril de 1840 una propuesta para que fuese revisado el texto del artículo 54 sobre los alcaldes, al entender que iba contra el artículo 79 de la Constitución y lo mismo pensaban Argüelles, Olózaga y otros. 
De Bernardo Ares, J.M. (1989): “La administración local de Córdoba durante la ocupación francesa” Studia Histórica, Historia Moderna, VII, pp. 653-664.

DE CASTRO, C. (1979): La Revolución liberal y los municipios españoles. Madrid.

DomínGuez ORTIZ, A. (1984): Sociedad y Estado en el siglo XVIII español (un intento de reforma municipal). Barcelona, Ariel.

ESTEPA, C. (1985): El nacimiento de León y Castilla (siglos XVIII-XI). Valladolid.

FERNÁNDEZ-CUESTA y MERELO, R. (1976): “Aspecto político y doctrinal de la Constitución de 1876” Anales de la Real Academia de Jurisprudencia y legislación. № 4, pp. 79-91.

FONT RIUS, J. M. (1949): “Orígenes del régimen municipal en Cataluña”. AHDE, 16, pp. 389-529.

Gallego AnAbitarte, A.; Barreiro Fernández, X.R. y González MariñAs, P., (1994): II Simposio de Historia da Administración. Santiago de Compostela.

GARCíA DE ENTERRÍA, E. (1981): Revolución Francesa y Administración Contemporánea y la formación del sistema municipal contemporáneo. Madrid, Taurus.

GaRCía de VALDEAVELLANO, L.

- (1968). Curso de historia de las Instituciones españolas. $3^{\mathrm{a}}$ Ed., Madrid.

- (1973): Historia de España. De los orígenes a la Baja Edad Media, Madrid.

GARCÍA FERNÁNDEZ, J.

- (2003): "El municipio en los orígenes del Constitucionalismo Español. Notas sobre la génesis de la organización municipal a través de tres modelos constitucionales", II seminario de Historia de la Administración. El Municipio Constitucional. Madrid, INAP, pp. 47-56.

- (1976): Esquema del Constitucionalismo español, 1808-1976. Madrid.

- (1983): El origen del municipio constitucional. Madrid, IEAL.

García GALlo (1952): Curso de historia del derecho español, Madrid.

GARRIGós PICO, E. (1982): “Organización territorial a fines del Antiguo Régimen” en M. Artola, La economía española a fines del Antiguo Régimen, Vol. III.

Gay ARmenteros, J. C. (1993): Política y administración en Javier de Burgos, Colección Perspectiva Histórica, Granada.

GoNZÁLEZ Alonso, B. (1970): El corregidor castellano (1348-1808), Estudios de historia de la administración, Instituto de estudios administrativos, Madrid.

GUBERT y SÁNCHEZ DE LA VEGA, R. (1949): El Concejo de Madrid, su organización en los siglos XIl y XIV. Madrid, IEAL.

GUILLAMÓN, J.

- (1988-90): “Algunos presupuestos metodológicos para el estudio de la administración. El régimen municipal en el siglo XVIII” en Revista de Historia Moderna. Anales de la Universidad de Alicante, pp. 57-74.

- (1988): "Reformismo institucional y gobierno municipal en el siglo XVIII" en Espacios urbanos, mundos ciudadanos, España y Holanda (siglos XVII-XVIII), Córdoba, pp. 65-82.

LIDA, C.E. (1997): “¿Qué son las clases populares? Los modelos europeos frente al caso español en el siglo XIX”, en Historia Social, N² 27, pp. 3-21.

MARINA BARBA, J. (1992): Poder municipal y reforma en Granada durante el siglo XVIII. Granada, Universidad de Granada.

MARTín RodrígueZ, J.L. (1985): Historia de Castilla y León. La afirmación de los Reinos. Siglos XII y XIII. Valladolid, Ambito, Vol IV.

MARTínez MARINA (1913): Teoría de las Cortes o Grandes Juntas nacionales de los Reinos de León y Castilla, Madrid.

Martínez RuedA, F. (1994): Los poderes locales en Vizcaya. Del Antiguo Régimen a la Revolución Liberal 17001853. Universidad del País Vasco, Bilbao. 
MERCHÁN FERNÁNDEZ, C.

- (1988): Gobierno municipal y administración local en la España del Antiguo Régimen, Tecnos, Madrid.

- (1988): La administración local de Palencia en el Antiguo Régimen (1180-1808), Diputación Provincial de Palencia, Palencia.

MONTANOS FERRÍN, E. (1992):"Las etapas fundamentales de la administración estatal en el Estado liberal” Historia de la Administración Pública, Xunta de Galicia, Santiago de Compostela.

ORduÑA Rebollo, E. (2003): Municipios y provincias, historia de la organización territorial española. Madrid.

ORTIZ DE ZÚNIIGA, M. y HERRERA, C. (1832): Deberes y atribuciones de los corregidores, justicias y ayuntamientos de España. I, Madrid.

PAREJo, A. (1988): Derecho Básico de la Administración local, Barcelona, Ariel.

PASOlA TEJEDOR, A. (1997): La historiografía sobre el municipio en la España moderna, Universidad de Lleida, Lleida.

PÉREZ PUYOL, E. (1986): Historia de las Instituciones sociales de la España goda. Valencia.

Pescador DEL Hoyo, M. C. (1986): El Concejo y las milicias de Madrid, Madrid.

PosAdA HerRerA, J. (1988): Lecciones de administración, Madrid, Instituto Nacional de Administración Pública.

RUEDA HERNANZ, G.

- (1985): “Del Antiguo Régimen a la primera expansión industrial (1808-1864)”. En: ALmuIÑA, C. et alii, Valladolid en el siglo XIX, Tomo VI, Ateneo de Valladolid, Valladolid, pp. 241-308.

- (2008): "El pueblo y el municipio, la comarca y el partido, la región y la provincia en la historia de España del XIX”. En: CARDELLS, F. (Ed). Actes I Congrés Universitari d' Història Comarcal, Carmar, Valencia, pp. $72-84$.

SÁNCHEZ AGESTA, L. (1984): Historia del Constitucionalismo español (1808-1936), Centro de Estudios Constitucionales, Madrid.

SÁNCHEZ AlboRnoz, C. (1943): Ruina y extinción del municipio romano en España e instituciones que lo reemplazan. Instituto de Historia de la Cultura Española Medieval y Moderna, Buenos Aires.

SARMIENTO LARRAURI, J. I. (1993): Antecedentes inmediatos de la figura del Gobernador Civil, Universidad Complutense de Madrid, Madrid.

TOMÁS Y VALIENTE

- (1976): "La venta de oficios de regidores y la formación de oligarquías urbanas en Castilla (siglos XVII y XVIII)", Jornadas de Metodología aplicada de las ciencias históricas. III Historia Moderna, Santiago de Compostela, pp. 551-568.

- (1977): “Origen bajomedieval de la patrimonialización y enajenación de oficios públicos en Castilla”, I Simposium de Historia de la Administración. Madrid, pp. 123-159.

- (1982): "Ventas de oficios públicos en Castilla durante los siglos XVII y XVIII" en Gobierno e instituciones en las España del Antiguo Régimen, Madrid, pp. 151-177.

VALDEÓn BARUQUE, J. (1989): “El origen del concejo abierto” en Jornadas sobre el Concejo Abierto, Valladolid, Junta de Castilla y León.

VARELA SUANZES-CAMPEGNA, J. (1984): “La Constitución española de 1837: Una Constitución transaccional”, en Revista de Derecho Político, № 20, pp. 95-106.

VIÑES MILLET, C. (1994): El municipio en España. Su evolución histórica. CEMCI, Granada. 
